\title{
STUDY OF ADVANCED TUNNEL FORMWORK SYSTEM IN HIGH RISE BUILDING
}

\author{
Tejas D. Aradhye ${ }^{1}$, Emeritus M. R. Apte ${ }^{2}$ \\ ${ }^{I}$ Post graduate Student, Construction and Management, Maharashtra Institute of Technology, Pune (Maharashtra, \\ India). \\ ${ }^{2}$ Professor Emeritus, Construction and management, Maharashtra Institute of Technology, Pune (Maharashtra, \\ India)
}

\begin{abstract}
Real estate construction industry has a reputation of not begin very technologically sophisticated, generally lagging in innovation, construction techniques \& management. But now a day's lot of research is carried out in this sector, advanced TUNNEL formwork \& ALUFORM system are good examples of this innovation. Formwork perform key role in construction. Formwork itself costs around 20-25\% of total cost of project. Also it requires minute level planning to achieve quality and economy. Advanced TUNNEL formwork system and ALUFORM system (Similar to MIVAN technology) are used to construct monolithic structures in which slab, beam \& walls are casted at one time which acts as RCC load bearing structure. This paper aimed at studying advanced tunnel formwork system in high rise building, to compare this system with Aluform system and to find best formwork in terms of economy and rapid construction.
\end{abstract}

Keywords: TUNNEL Formwork, ALUFORM System, Slab Cycle, Economy.

\section{INTRODUCTION}

Formwork is a temporary or permanent mould including supporting structures, in which concrete is poured. Formwork supports this poured concrete until it gains strength sufficient to carry its own weight and live loads on it. Formwork should be capable of carrying all dead load and live load $\mathrm{s}$ on it. In order to successfully carry out its function, formwork must achieve a balance of resistance to leakage, containment, strength, accuracy, finish and reuse potential, access for concerted. Formwork planning process is divided in 3 stages

First stage: The necessary information and limiting conditions must be collected and defined. When projects of similar nature are executed, a checklist can be of immense help in obtaining information required to prepare a complete scheme.

Second stage: The formwork system to be used can be selected. In addition to cost of the materials, the choice of the system will be influenced by the experience of the planner and of the team, which has to set up the formwork on the site, and by the project archive. A database / project archive that captures the experience gathered over the years can aid in cost effective system selection.

Third stage: This involves all engineering design tasks. This part of the process is most time consuming. It is important to be able to allow for changes arising at later phases of the project. The emphasis should be on maximum reuse of materials available and procuring minimum materials Just-In-Time.

\section{OBJECTIVE}

Objective of study is to study tunnel formwork systems \& after to compare with Aluform system on basis on

1. Slab cycle time

2. Cost parameters.

3. Quality parameters.

And hence to suggest best formwork system for in high rise building.

\section{THEORETICAL CONTENT}

Formwork planning process is divided in 3 stages.

Stage 1: Information, data collection and examination of limiting conditions.

Stage 2: Analysis of system \& choice of system based on information collected

Stage 3: Use of system in construction.

Depending upon purpose of use, method of erection various types of formwork systems are selected. Various types of formwork are available varying from traditional formwork to permanent formwork depending on its purpose. The formworks for vertical concreting are generally called wall forms and those for horizontal concreting are called slab or floor forms. These formwork systems varies from conventional to advanced MIVAN, TUNNEL formwork systems having slab cycle of 1-3 days.

\section{Aluminum formwork system / ALUFORM system}

The System is fast, simple, adaptable and very cost effective. Aluform is advanced formwork system in which cast in place concrete structured building can be constructed. The system 
is fast (7-10 days slab cycle), simple to use easily adaptable and very cost effective as number of reuses are more i.e. about 150-200. As we can construct all building components such as slabs, beams, columns, walls, stairs, window hoods etc.

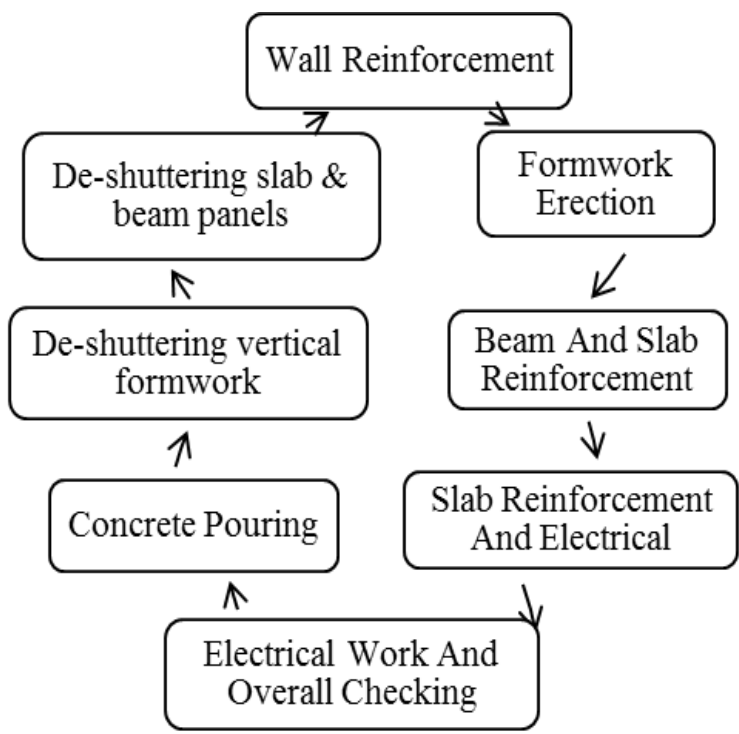

Fig 1: Slab cycle of ALUFORM system.

The smooth wall finish after Deshuttering eliminates need of wall plastering and we get direct paint finish. Monolithic RCC load bearing structure formed by continuous pouring concrete in walls and slabs in same operation. Extraordinary seismic resistant structure with greater efficiency and smooth finish is achieved by using Aluform system.

Due to consistent concrete shapes and finishes are obtained floor to floor prefabricated electrical and plumbing components are used to increase speed of construction as we know exact positions of these components. Panels are held in position by simple stup pin wedge system which is easy to fix and remove.

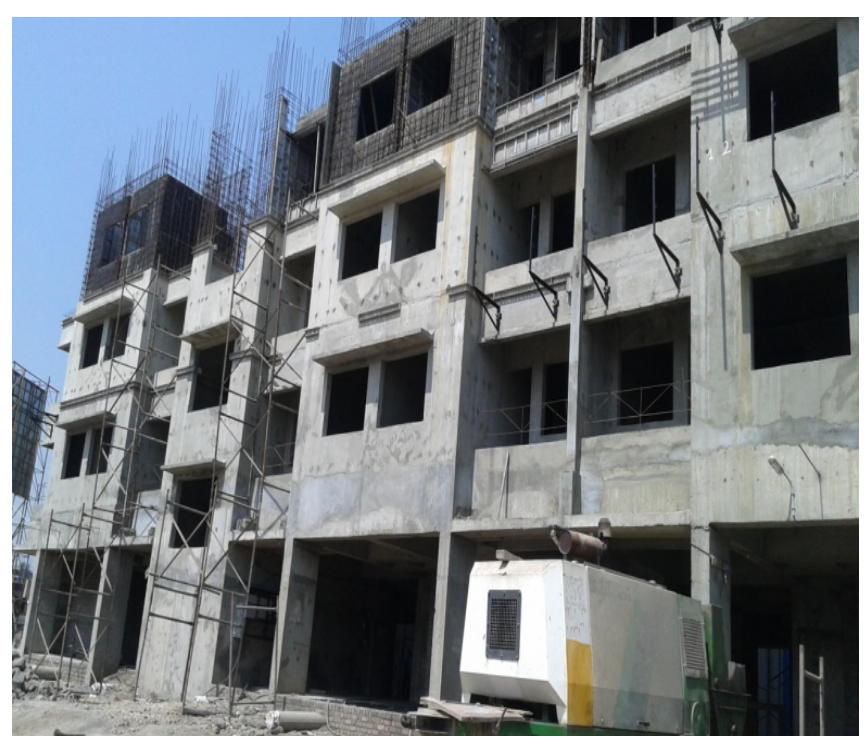

Fig 2 : Construction using ALUFORM system.

\section{TUNNEL Formwork System}

The tunnel formwork is room sized steel formwork by which monolithic structures i.e. RCC walls and slabs are constructed in continuous pour. Thermal curing technique is used to accelerate curing of concrete for which tunnel forms are heated by means of hot air blows. This system is economical only for large number of identical units and for tall structures or skyscrapers. The sequence of construction involves placing of reinforcement followed by electrical and sanitary conduits fittings along with tunnel forms.

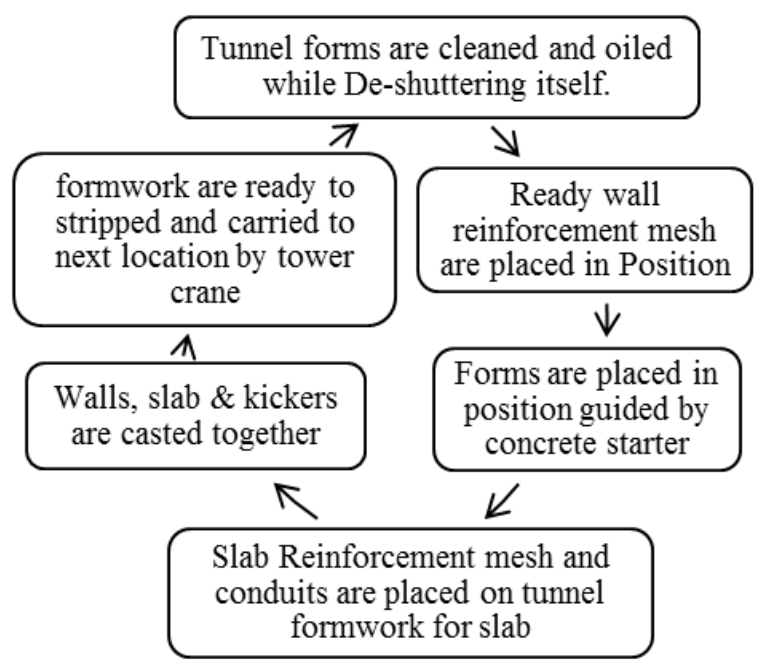

Fig 3: Slab cycle of tunnel formwork

After pouring concrete gas heaters are placed inside shutters and open face of shuttering is closed by heat resistant curtains. Forms are then removed and placed on next floor or adjacent side using tower cranes as per requirement. Optimum use of tunnel form is possible in very tall structures with identical floor layout or large projects where identical units are to be constructed.

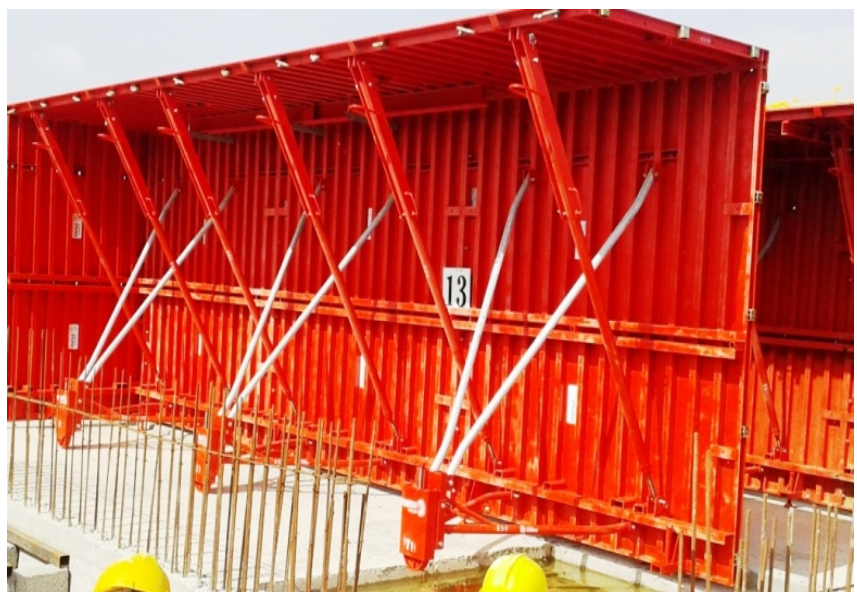

Fig 4: Typical half tunnel form.

\section{CASE STUDY}

For project work two different sites were studied, Rohan Builders India Pvt Ltd is using advanced TUNNEL formwork system (1-3 days slab cycle) and Naiknavare Developers using advanced ALUFORM system (Slab cycle of 8-12 days). 
Table 1: Table summarizing case studies

\begin{tabular}{|l|l|l|l|}
\hline $\begin{array}{l}\text { Sr. } \\
\text { No }\end{array}$ & Details & Case study I & Case study II \\
\hline 1 & Name of firm & Rohan Builders India Pvt. Ltd, Pune & Naiknavare Developers, Pune \\
\hline 2 & Name of project & Rohan Abhilasha Wagholi, Pune & $\begin{array}{l}\text { Slum Rehabilitation Scheme (SRA) Dandekar Bridge, } \\
\text { Pune }\end{array}$ \\
\hline 3 & Type of project & Residential & Residential \\
\hline 4 & Type of system used & TUNNEL formwork & ALUFORM system \\
\hline 5 & Area for data collection & Wing A2 of 'A' block & SRA scheme \\
\hline 6 & $\begin{array}{l}\text { Consultant hired for } \\
\text { system }\end{array}$ & $\begin{array}{l}\text { MESA Imalat } \\
\text { Hi Tek Insat }\end{array}$ & Naiknavare Developers \\
\hline 7 & Slab Area & 13568 sq. meter & 9720 sq. m. \\
\hline
\end{tabular}

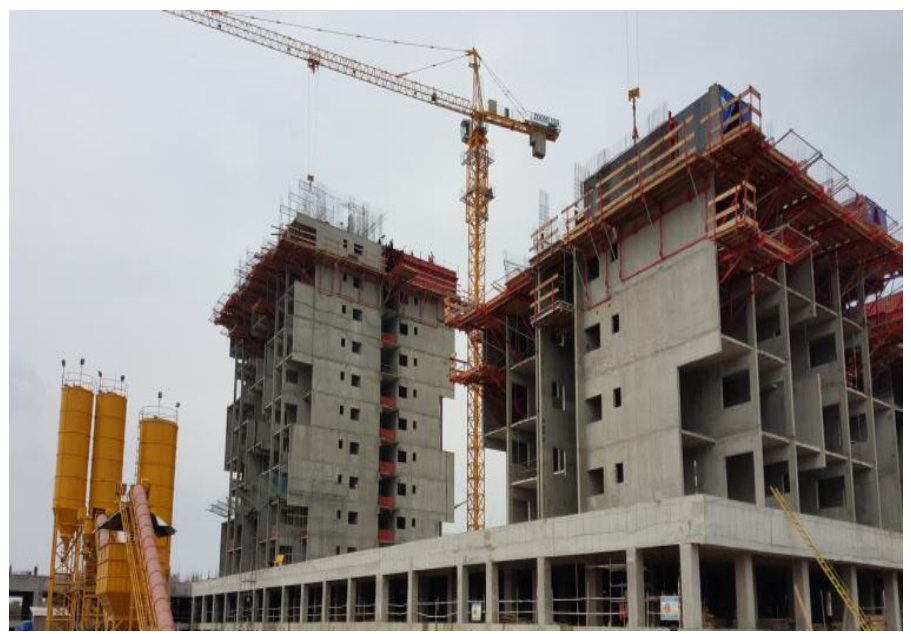

Fig 5: Construction using TUNNEL formwork

\section{V: DATA COLLECTION}

1. Data collected from both site is as below:

2. Plan, Section of building

3. MS Project schedule

4. Quantity estimates of material (Steel, Concrete \& formwork)

5. Formwork technical manuals \& user guide.

6. On site factual data collection.

\section{DATA ANALYSIS \& FINDINGS FROM}

\section{STUDY}

For optimizing current slab cycle of tunnel formwork based three possible alternatives were considered, where we can reduce time in each slab cycle.

1. Concreting operations.

2. Crane operation.

3. By increasing quantity of formwork.
Alternative 1: Reducing time in concreting operations.

Due to added hyper plasticizers setting time of concrete is reduced as per demand of site engineers to achieve slab cycle of 4 days. Also longer pipeline (about 110 meter) leads to setting of concrete in pipeline itself which causes choke up problem with concrete pump.Difference between output capacity of batching plant and input capacity of concrete pump causes segregation and hence choking of concrete pump. These problems can be overcome by using 2 transit mixers for concreting activity.

\section{Alternative 2: Reducing time in crane operation.}

Second alternative available is reducing time by optimizing tower crane operations. From bar chart drawn it is clear that tower crane remain idle for 2 hours every day. This time can be used for activities in next day, but as all activities are to be carried out in continuous manner we cannot reduce time by using tower crane for next day activity. However we can use this time to carry out other works such as moving material to store, moving material from store to required position etc.

\section{Alternative 3: Increasing quantity of shutters.}

At present $50 \%$ of quantity per floor is being used Increasing quantum of shutters can be one of the alternative but it leads to subsequent increase in heavy machinery, highly skilled labour and initial investment.

Hence out of 3 alternatives only $3^{\text {rd }}$ alternative may possible in construction of skyscrapers in very large area them this system will become economical.

Summarized table showing general comparison of tunnel formwork system and Aluform system is shown below. 
Table 2: General comparison of tunnel formwork versus Aluform

\begin{tabular}{|c|c|c|}
\hline Details & Aluform system & Tunnel formwork system \\
\hline Capital Cost & $\begin{array}{l}\text { Cost of shuttering material is high } \\
\text { (Around } 10000 \text { per m2) }\end{array}$ & $\begin{array}{l}\text { Cost of shuttering material and other related } \\
\text { machinery is very high }(25000 \text { per } 2)\end{array}$ \\
\hline Casting System & $\begin{array}{l}\text { Monolithic structure of walls and } \\
\text { ceiling casted together }\end{array}$ & $\begin{array}{l}\text { Monolithic structure of main walls and ceiling } \\
\text { casted together } \\
\text { Internal portion walls build after words }\end{array}$ \\
\hline $\begin{array}{l}\text { Accuracy and Quality of } \\
\text { construction }\end{array}$ & Good accuracy but with proper care & Good accuracy \\
\hline Design Changes & $\begin{array}{l}\text { Used for Repetitive design/mass } \\
\text { construction. Changes in design is } \\
\text { difficult to incorporate }\end{array}$ & $\begin{array}{l}\text { Used for Repetitive design/ mass construction. } \\
\text { Changes in design is difficult to incorporate. }\end{array}$ \\
\hline Special Machinery & Not required & $\begin{array}{l}\text { Require } 10 \text { ton capacity Crane, } 60 \text { to } 80 \mathrm{~m} 3 \\
\text { batching plant, Mesh Welding Machine }\end{array}$ \\
\hline Labour Cost & Around Rs 175 to $200 / \mathrm{Sft}$ slab area & $\begin{array}{l}\text { Around Rs } 175 \text { to } 200 \mathrm{sft} / \mathrm{slab} \text { area initially, } \\
\text { Can reduce to Rs } 75 \text { to } 100 / \mathrm{sft} \text { after proper } \\
\text { training of in-house workers }\end{array}$ \\
\hline Staff on Site & Require More & Less than other two systems \\
\hline Safety & Safe & $\begin{array}{l}\text { If proper precaution taken then safe, } \\
\text { crane operation is critical }\end{array}$ \\
\hline No of Reuses & 100 to 150 & $500+$ \\
\hline
\end{tabular}

\section{CONCLUSION}

Real estate construction industry has a reputation of not begin very technologically sophisticated, generally lagging in innovation, construction techniques \& management. But now a day's lot of research is carried out in this sector, advanced TUNNEL formwork \& ALUFORM system are good examples of this innovation. We can achieve 1-3 days slab cycle by TUNNEL formwork system, where as we also can use ALUFORM or MIVAN system by which we can achieve slab cycle of 7-10 days. Considering Indian conditions tunnel formwork if used $100 \%$ quantum of slab, as it involve heavy investment in procurement, heavy machineries, specialized expert labour it becomes uneconomical. In case project involves more than 20 storied building over large area, total economics may change considerably. However this aspect will require further study to arrive at conclusion. Also after studying and comparing both the systems it can be concluded that, though initial investment and per day operational cost in TUNNEL formwork is more than ALUFORM system, due to more reuses and reduced slab cycle time TUNNEL formwork works out ultimately economical. Also returns from initial investment regained due rapid completion of project Hence in long term consideration TUNNEL formwork system is beneficial than that of ALUFORM system.

\section{REFERENCES}

[1] Patil Dhanashri Suryakant and Prof. Desai D B, "Emerging Trends in Formwork - Cost Analysis \& Effectiveness of Mivan Formwork over the Conventional Formwork" IOSR (IOSR-JMCE) ISSN: 2278-1684, PP: 27-30

[2] S. A. Anuar, N. H. Hamid, M. H. Hashim, S. M. D. Salleh, "Comparison of Double Unit Tunnel Form Building before and after Repair and Retrofit under inPlane Cyclic Loading", International Journal of Civil, Environmental, Structural, Construction and Architectural Engineering Vol:8, No:12, 2014.

[3] Dilek Tezgelen and Ozgul Yilmaz Karaman, "Evaluation of user comfort in tunnel formwork housing :Izmir as a Case Study" , Archnet-IJAR, International Journal of Architectural Research 2014.

[4] Yaser Sotoudeh, Mozhdeh Salehi, Saeed Moradzadeh, Homayoon Taghipoor, Meisam Behboodi, Building technology for mass concrete tunnel form method", Advances in Environmental Biology, 7(9): 2190-2194, 2013 ISSN 1995-0756.

[5] Sandip.P.Pawar and P.M.Atterde, "Comparative analysis of formwork in multistory building", IJRET:, Volume: 03 Special Issue: 09, June-2014.

[6] Mr. Shankar Bimal Banerjee, Mr. Pawan Dilip Barhate and Mr. Vipul Pradip Jaiswal "Mivan Technology", [ijiert] issn: 2394-3696 volume 2, issue 3 march2015. 
[7] Taehoon Kim, Hunhee Cho*, and Kyung-In Kang "Form work management based on ubiquitous computing for high-rise building construction", School of Civil, Environmental and Architectural Engineering, Korea University, Seoul, Korea.

[8] Hisham A. Abou Ibrahim and Farook R. Hamzeh, "Role of formwork systems in high-rise construction" 5th International/11th Construction Specialty Conference construction Vancouver, British Columbia June 8 to June 10, 2015.

[9] Sameer S. Malvankar, "Factors Affecting the Selection, Economics Involved in Formwork" The master builder, July 2013, www.masterbuilder.co.in

[10]Name of the author: Ramesh Kannan.M, Helen Santhi.M, "Constructability Assessment of Climbing Formwork Systems Using Building Information Modelling", Science direct, Procedia Engineering 64 ( 2013 ) 1129 - 1138.

[11] Prathul U, Leeladhar Pammar, Analysis of Productivity by Comparing Mivan and Conventional Formwork, (JETIR -ISSN-2349- 5162) (ww.jetir.org), April 2015, Volume 2, Issue 4.

[12] Ninjal M Parekh, Bhupendra M Marvadi, Umang Patel, comparative studies of construction Techniques (conventional technique vs. Aluminium Formwork techniques), journal of information, knowledge and research in Civil engineering, ISSN: 0975 - 6744| NOV 14 TO OCT 15 | Volume 3, Issue 2.

[13]Dunne group ltd. Cellular construction using tunnel form, Dunne Group Ltd Tunnel Form 2009

[14] MESA imalat, "Modular Tunnel Formwork System: User Manual",

[15] Larson \& turbo building structure competency centre, "Hand Book on Foundation, Formwork, Rebar \& Concrete. 